\title{
Pulmonary arterial pressures, arterial blood-gas tensions, and serum biochemistry of beef calves born and raised at high altitude
}

This article was published in the following Dove Press journal:

Open Access Animal Physiology

12 July 2013

Number of times this article has been viewed

\section{Joseph M Neary' \\ Franklyn B Garry' \\ Timothy N Holt ${ }^{1}$ \\ Anthony P Knight' \\ Daniel H Gould ${ }^{2}$ \\ David A Dargatz ${ }^{3}$}

'Integrated Livestock Management, Department of Clinical Sciences,

${ }^{2}$ Veterinary Diagnostic Laboratory,

Colorado State University,

${ }^{3}$ USDA:APHIS:VS Centers

for Epidemiology and Animal Health,

Fort Collins, CO, USA
Correspondence: JM Neary

Department of Clinical Sciences,

Colorado State University,

1678 Campus Delivery, Fort Collins,

CO 80523-1678, USA

Email joe.neary@colostate.edu
Abstract: High-altitude exposure is physiologically challenging. This is particularly true for animals native to low-altitude environments, such as British breeds of cattle. The objective of this study was to document the effect of high altitude on select physiological parameters of healthy beef calves (Bos taurus) born and raised on a high-altitude ranch typical of the Rocky Mountain region. Pulmonary arterial pressures, arterial blood-gas tensions, serum biochemistry, and hematocrit were evaluated. The calves studied were a composite of British (50\%-75\%) and Continental $(25 \%-50 \%)$ breeds born on one ranch at an altitude of $2410 \mathrm{~m}$. Calves were sampled at an altitude of $2410 \mathrm{~m}$ when 1 month old and again at an altitude of $2730 \mathrm{~m}$ when 3 and 6 months old. Between 3 and 6 months of age, calves had access to grazing from $2730 \mathrm{~m}$ to approximately $3500 \mathrm{~m}$ above sea level. On each occasion, 16 to 50 calves were sampled. Only calves that remained healthy throughout all three testing periods were included in the dataset. Calves with the highest pulmonary arterial pressures at 1 month of age tended to have the highest pressures at 6 months of age $(\mathrm{r}=0.43, P=0.16, \mathrm{n}=12)$. Respiratory alkalosis was greatest at 6 months of age ( $\mathrm{pH} 7.48 \pm 0.06)$. Mean alveolar-arterial oxygen pressure gradients were 11.7 and $11.6 \mathrm{mmHg}$ at 3 and 6 months of age, indicating poor transfer of oxygen from the alveoli into the pulmonary blood. Median values for blood lactate ranged from 1.4 to $3.4 \mathrm{mmol} / \mathrm{L}$ indicating substantial anaerobic respiration at all ages. Mean hematocrits were $\leq 35.7 \%$, only slightly higher than values obtained from age-matched calves at sea level. These results suggest that the provision of oxygen to the peripheral tissues of beef calves may be compromised at altitudes over $2410 \mathrm{~m}$. This may have implications for diseases of the cardiopulmonary system.

Keywords: altitude, pulmonary artery pressure, biochemistry, blood gas, hypertension, calves

\section{Introduction}

Extreme physiological stressors such as fluctuating temperatures, low-oxygen tension, rugged terrain, and intense solar radiation are characteristic of high-altitude environments. Species that have inhabited such environments over thousands of years have evolved to cope with these stressors. For example, the Himalayan yak (Bos grunniens), in the same genus as domestic European cattle (Bos taurus), has, among other adaptations to high altitude, a thick hair coat, a blunted hypoxic pulmonary vasoconstrictive response, and thin-walled pulmonary vessels. ${ }^{1}$

There are six US states with a mean altitude of $1500 \mathrm{~m}(5000 \mathrm{ft})$ or higher: Colorado, Idaho, Nevada, New Mexico, Utah, and Wyoming. These six states, which encompass the central and southern aspect of the Rocky Mountain range, are home to 2.9 million beef cows and primiparous heifers. ${ }^{2}$ British breeds of cattle (B. taurus) 
were the first cattle to be introduced to the Rocky Mountain region in the mid-19th century. These lowland cattle breeds, such as Hereford and Aberdeen Angus, originate from, and are accustomed to, altitudes that are marginally above sea level. They have been afforded little evolutionary time to adapt to the stressors of high altitude. Consequently, there are drawbacks to the production of cattle at high altitude. $B$. taurus cattle are prone to developing pulmonary hypertension at high altitude. ${ }^{3}$ Indian cattle (Bos indicus, the zebu) tolerate the high-altitude regions of the Himalayas and Ethiopia without problems. ${ }^{4}$

An investigation of beef calf mortality on high-altitude ranches revealed a high risk of calf mortality due to respiratory disease and/or pulmonary hypertension. ${ }^{5}$ In order to meet oxygen requirements in a high-altitude environment, the stress on a growing calf's cardiopulmonary system may be considerable. Despite the health and economic livelihood implications, there has been little attention paid to the effect of high altitude on bovine calf physiology. The objective of this study was to characterize select physiological parameters of beef calves born and raised in a high-altitude environment. In this study, pulmonary arterial pressures, arterial blood gases and serum biochemistries were determined for beef calves at 1, 3, and 6 months of age at altitudes ranging from $2410 \mathrm{~m}$ to $2730 \mathrm{~m}$.

\section{Methods}

\section{Study site and herd management}

The study was conducted on one ranch in Gunnison County, CO, USA and approved by the Colorado State University Animal Care and Use Committee. The calves studied were a composite breed of British (50\%-75\%) and Continental (25\%-50\%) genetics. Calves were tagged at birth. Calves were born from 20 March to 25 April, 2010. A clostridial vaccine containing Mannheimia haemolytica bacterin (One Shot Ultra 8; Pfizer Animal Health, Inc, Madison, NJ, USA) plus growth hormone implant (Synovex C; Pfizer Animal Health, Inc) was given at branding to both heifers and steers (15-17 May, 2010). Cows and heifers were given a prebreeding modified live respiratory disease vaccine offering protection against bovine herpesvirus 1 (infectious bovine rhinotracheitis), bovine viral diarrhea (BVD) virus, bovine respiratory syncytial virus (BRSV), and bovine parainfluenza virus 3 (BoviShield Gold 5; Pfizer Animal Health, Inc). Calves were not given a respiratory disease vaccine until 2 weeks prior to weaning (5 October, 2010). Ear notch samples are routinely taken every year from all calves kept as replacement heifers on the study ranch for individual BVD virus enzyme-linked immunosorbent assay testing. No calves persistently infected with BVDV have been detected to date.

Bulls must have a mean pulmonary arterial pressure $\leq 42 \mathrm{mmHg}$ when measured at $2410 \mathrm{~m}$ to be a herd sire on the study ranch. This selection criterion has been used on all potential herd sires since 1981, when pulmonary arterial pressure testing was first performed. Each year, 250-350 female calves are retained as replacement heifers that is, females for future breeding. No females are brought in from an outside herd. Therefore, all females within the herd are progeny of low pulmonary arterial pressure bulls and have genetics predisposing to low pulmonary arterial pressure. Females are not pulmonary arterial pressure tested. Low pulmonary arterial pressure $(\leq 42 \mathrm{mmHg})$ composite bulls $(50 \%-75 \%$ British and 25\%-50\% Continental genetics) were bred to the dams used in this study: one bull for every 15 heifers, on average. The bulls were removed after 30 days' exposure to the heifers. Non-pregnant heifers are typically sold. All bulls are kept at an elevation of at least $2410 \mathrm{~m}$ year round.

\section{Sampling procedure}

Calves studied were born to primiparous 2-year-old heifers. All dams were healthy at calving time and during the testing period. All calves were born with minimal or no assistance. Calves were born at $2410 \mathrm{~m}$ and transported to summer grazing at $2730 \mathrm{~m}$ on 25 June, 2010. From this date until late September, the cow-calf pairs had access to grazing from $2730 \mathrm{~m}$ to approximately $3500 \mathrm{~m}$ above sea level. In early October, all animals were moved from the grazing permits to private land at a lower elevation of $2730 \mathrm{~m}$.

The calf-testing schedule is outlined in Table 1. The dams of the calves tested at age 3 months were also tested on the same day: 2 July, 2010. Repeat measures were performed on calves at 3 and 6 months of age, on 2 July and 5 October, 2010 respectively, unless they were excluded from the study due to ill health or death. If excluded, all values associated with that individual were excluded from the dataset. Calves were restrained in a chute for sampling.

\section{Pulmonary arterial pressure testing}

Pulmonary arterial pressure testing is used as a screening test in cattle for pulmonary hypertension so that appropriate management and breeding decisions can be made. Flexible saline-filled catheter tubing is passed through a large bore needle inserted into the jugular vein down through the right atrium, into the right ventricle, and then into the pulmonary artery. A pressure transducer 
Table I Animal-testing schedule

\begin{tabular}{|c|c|c|c|c|c|c|c|}
\hline Date & $\begin{array}{l}\text { Animal } \\
\text { tested }\end{array}$ & $\begin{array}{l}\text { Average age, } \\
\text { months }\end{array}$ & $n^{\prime}$ & $\mathbf{n}$ & Reason for exclusion & $\begin{array}{l}\text { Number of calves } \\
\text { previously tested }\end{array}$ & Altitude, $\mathrm{m}$ (ft) \\
\hline I5 May & Calves & 1 & 16 & 12 & $\begin{array}{l}\text { I. Septic joint }(n=1) \\
\text { 2. Died }(n=3)\end{array}$ & - & 2410 m (7907) \\
\hline 2 July & Calves & 3 & 24 & 21 & I. Died $(n=3)$ & 12 from May & 2730 m (8957) \\
\hline & Cows & $24-27$ & 23 & 23 & - & - & $2730 \mathrm{~m}$ \\
\hline 5 October & Calves & 6 & 50 & 48 & $\begin{array}{l}\text { I. Clinical signs of pulmonary hypertension } \\
\text { 2. Died }(n=I)\end{array}$ & $\begin{array}{l}\text { II tested in May and July } \\
8 \text { tested in July only }\end{array}$ & $2730 \mathrm{~m}$ \\
\hline
\end{tabular}

Abbreviations: $n$, total number of animals included in the analysis; $\mathrm{n}^{\prime}$, total number of animals sampled.

connecting the catheter to an oscilloscope provides a reading of the mean, systolic, and diastolic pulmonary artery pressures. The jugular vein, atrium, ventricle, and pulmonary artery have distinct pressure waveforms from which it is possible to determine catheter placement. ${ }^{6}$ A full description of the equipment, materials, and facilities required for pulmonary arterial pressure testing is provided elsewhere. ${ }^{6}$

\section{Alveolar-arterial oxygen pressure gradient}

Blood-gas analysis was performed using a handheld analyzer (VetScan i-STAT 1; Abaxis, Union City, CA, USA). Sample analysis takes 2 minutes and the results are automatically stored under the animal identification number.

Arterial blood was collected from the coccygeal artery using a 22-gauge, $2.54 \mathrm{~cm}\left(1^{\prime \prime}\right)$ hypodermic needle. The coccygeal artery is a suitable source of blood from bovines for blood-gas analysis. ${ }^{7,8}$ Arterial blood, unlike venous blood, can fill a preheparinized syringe without applying suction. Therefore, minimal, if any, negative pressure was applied to the syringe chamber by drawing on the plunger when obtaining a sample. Approximately $2-2.5 \mathrm{~mL}$ of blood was collected in a $3 \mathrm{~mL}$ syringe. Syringes were heparinized with approximately $0.25 \mathrm{~mL}$ of sodium heparin $(1000 \mathrm{IU} / \mathrm{mL})$. The plunger of each syringe was pulled back to the $3 \mathrm{~mL}$ mark, coating the inner chamber surface with heparin. Heparin was then expelled so that only the needle hub contained heparin. Collection of blood up to the $2 \mathrm{~mL}$ mark results in dilution of the blood sample by $<5 \% .{ }^{9}$ This is sufficient to minimize preanalytic error associated with dilution. ${ }^{10}$ The sample was discarded if, during collection, the flow of arterial blood was interrupted. Air bubbles within the blood were immediately expelled and the first several drops of blood discarded before one to three drops of blood ( $95 \mu \mathrm{L}$ required) were placed on an i-STAT cartridge. A temperature "correction" algorithm was used to adjust blood-gas tensions according to rectal temperature. ${ }^{11}$
The alveolar-arterial oxygen pressure gradient is an indicator of the ease of oxygen transfer from the alveoli to the pulmonary blood. An alveolar-arterial oxygen pressure gradient $>10 \mathrm{mmHg}$ is an indicator of poor oxygen transfer due to ventilation-perfusion mismatching, diffusion impairment, or right-to-left vascular shunt. ${ }^{12}$ The alveolar-arterial oxygen pressure gradient is calculated using the following formulae:

$$
\begin{gathered}
\text { A-a } \mathrm{O}_{2} \text { pressure gradient }=\mathrm{P}_{\mathrm{A}} \mathrm{O}_{2}-\mathrm{PaO}_{2} \\
\mathrm{P}_{\mathrm{A}} \mathrm{O}_{2}=\mathrm{FiO}_{2}\left(\mathrm{BP}-\mathrm{pH}_{2} \mathrm{O}\right)-\left(\mathrm{PaCO}_{2} / \mathrm{R}\right),
\end{gathered}
$$

where $\mathrm{P}_{\mathrm{A}} \mathrm{O}_{2}=$ alveolar $\mathrm{O}_{2}$ tension $(\mathrm{mmHg}) ; \mathrm{PaO}_{2}=$ arterial $\mathrm{O}_{2}$ tension $(\mathrm{mmHg}) ; \mathrm{PaCO}_{2}=\operatorname{arterial~} \mathrm{CO}_{2}$ tension $(\mathrm{mmHg}$ ); $\mathrm{R}=$ respiratory exchange ratio (0.9); $\mathrm{FiO}_{2}=$ fraction of inspired $\mathrm{O}_{2}(0.21)$; $\mathrm{BP}=$ barometric pressure $(\mathrm{mmHg})$; and $\mathrm{pH}_{2} \mathrm{O}=$ water vapor pressure at body temperature $\left(52.4 \mathrm{mmHg}\right.$ at $\left.39^{\circ} \mathrm{C}\right)$.

The respiratory exchange ratio, determined by dividing $\mathrm{VCO}_{2}$ exhaled by $\mathrm{VO}_{2}$ inhaled, varies according to energy source (pure carbohydrate $R=1$, pure fat $R=0.7$ ). A study of seven cows at least 2 years old reported a mean respiratory exchange ratio of $0.91( \pm 0.05) .{ }^{13}$ A respiratory exchange ratio for pre-weaned calves could not be found, therefore, a value of 0.9 was used in this study. Previous studies ${ }^{14,15}$ have used a respiratory exchange ratio of 1.0 , which increases their estimates of alveolar-arterial oxygen pressure gradient relative to the present study.

\section{Biochemistry and hematocrit}

Approximately $8 \mathrm{~mL}$ of blood was acquired from the jugular vein using the same large-bore needle as in pulmonary arterial pressure testing. Of that blood, 3-4 mL was placed into $5 \mathrm{~mL}$ ethylenediaminetetraacetic acid (EDTA) tubes and inverted several times. The remaining blood was placed into a $10 \mathrm{~mL}$ glass collection tube. After allowing for clotting (30-60 minutes), the blood, in $10 \mathrm{~mL}$ glass collection tubes, was spun at $1100 \times g$ for 15 minutes (Clay Adams Dynac 
centrifuge, BD, Franklin Lakes, NJ, USA). Serum was stored at $5^{\circ} \mathrm{C}$. Serum biochemistry (Hitachi 917; Roche Diagnostics Inc, IN, USA) and complete blood counts (Advia 120; Siemens Healthcare Diagnostics Inc, NY, USA) were performed the following morning.

\section{Statistical analysis}

All statistical analyses were performed using STATA version 12 (Stata Corporation, College Station, TX, USA). Since a proportion of calves were tested on more than one occasion, generalized estimating equations were performed to determine significant differences in the dependent physiological variables according to the independent variable, the month of testing. Generalized estimating equations account for repeat measures taken from the same calves tested in different months and also account for calves not tested on more than one occasion. An exchangeable correlation matrix was used.

\section{Results}

\section{Pulmonary arterial pressure}

The average pulmonary arterial pressure for all calves trended upwards from 1 month of age to 6 months of age $(P<0.001)$. Autocorrelation of mean pulmonary arterial pressure was moderately high between 1 and 6 months of age $(r=0.43$, $P=0.16, \mathrm{n}=12)$ and between 3 and 6 months of age $(\mathrm{r}=0.44$, $P=0.05, \mathrm{n}=20)$, but considerably lower between 1 and 3 months of age $(\mathrm{r}=0.18, P=0.55, \mathrm{n}=14)$.

Steers tended to have higher mean pulmonary arterial pressures than heifers at all ages (Table 2) $(P=0.16)$. There was no difference in mean pulmonary arterial pressure scores between the 3-month-old calves and their dams $(P=0.78)$.

\section{Pulmonary gaseous diffusion and hematocrit}

Table 3 summarizes measures of pulmonary gaseous diffusion for calves and cows. Both calves and cows showed respiratory

Table 2 Mean pulmonary arterial pressures by age and sex

\begin{tabular}{lllll}
\hline Age, months & Sex & $\mathbf{n}$ & $\begin{array}{l}\text { Mean pulmonary arterial } \\
\text { pressure, } \mathbf{m m H g}\end{array}$ & SD \\
\hline I & Heifer & 4 & 34.3 & 4.2 \\
3 & Steer & 8 & 34.9 & 7.6 \\
& Heifer & 8 & 41.9 & 5.4 \\
6 & Steer & 13 & 42.6 & 9.0 \\
& Heifer & 25 & 50.5 & 10.5 \\
$24-27$ & Steer & 23 & 54.4 & 10.6 \\
\hline
\end{tabular}

Abbreviations: $n$, number of animals tested; SD, standard deviation. alkalosis. The $\mathrm{pH}$ of arterial blood from calves increased from 1 month to 6 months of age $(P<0.001)$. Mean arterial $\mathrm{CO}_{2}$ tension decreased from 1 month to 3 months $(P<0.001)$ and from 1 month to 6 months of age $(P=0.006)$, indicating more pronounced hyperventilation, and therefore respiratory alkalosis, with increasing age.

Cows had a lower alveolar-arterial oxygen pressure gradient than their calves $(P=0.02)$ (Table 3$)$. L-lactate, an indicator of anaerobic respiration, was high for both calves and cows.

Both hematocrit and hemoglobin concentrations were lower for cows than calves $(P=0.05)$. Oxyhemoglobin saturation was higher for calves at $3(P=0.005)$ and $6(P=0.007)$ months of age than for calves at 1 month of age.

\section{Biochemistry}

Serum biochemical parameters are summarized in Table 4. Calf total calcium concentrations were higher than that of cows $(P<0.001)$. Total calcium concentrations were higher at $1(P=0.04)$ and $6(P=0.007)$ months of age than at 3 months of age. Calf serum phosphorous was higher than that of cows $(P<0.001)$. In calves, average phosphorous concentrations increased significantly from 1 month to 3 months of age $(P=0.006)$ before dropping to a lower average at 6 months of age. Average creatinine concentrations were similar between calves at 3 months old and their dams. In calves, average creatinine concentrations were higher at 6 months of age than at either $1(P<0.001)$, or $3(P<0.001)$ months of age. Sodium, chloride, and magnesium concentrations are similar to prior studies. ${ }^{16,17}$

\section{Discussion}

High-altitude environments pose physiological stressors to all animals, but particularly to lowland breeds of livestock such as British breeds of cattle. Physiological parameters of calves born and raised at an altitude over 2410 m (7907 ft) may differ from calves raised at a lower altitude. Few studies of calf physiology have been conducted at high altitude. For this reason, we determined the pulmonary arterial pressures, arterial blood gases, and serum biochemistries of healthy calves born and raised on one ranch over $2410 \mathrm{~m}$. Samples were taken at 1, 3, and 6 months of age.

Mean pulmonary arterial pressure trended upwards with age, supporting the observation that the risk of pulmonary hypertension, or high altitude disease in calves is greatest in the autumn months. ${ }^{18}$ Age was confounded by seasonal climate change and altitude variation. However, the pattern of events documented in this study is common for calves raised 
Table 3 Arterial blood variables associated with pulmonary function and acid-base status

\begin{tabular}{|c|c|c|c|c|c|c|}
\hline Variable & Cow/calf & Age, months & $\mathbf{n}$ & Mean & SD & Reference interval \\
\hline \multirow{6}{*}{$\mathrm{P}_{\mathrm{a}} \mathrm{CO}_{2}, \mathrm{mmHg}$} & Calf & 1 & 11 & $40.9^{a}$ & 4.0 & $42.9 \pm 0.8(\text { sea level, } n=I I)^{23}$ \\
\hline & & & & & & $45.8 \pm 3.0(\text { sea level, } n=6, \text { sea level })^{14}$ \\
\hline & & & & & & $42.8 \pm 3.3^{15}$ \\
\hline & & 3 & 13 & $34.5^{\mathrm{b}}(P<0.00 \mathrm{I})$ & 3.2 & $45.8 \pm 2.3^{14}$ \\
\hline & & 6 & 37 & $37.0^{\mathrm{b}}(P=0.006)$ & 4.3 & $47.3 \pm 3.0^{14}$ \\
\hline & Cow & $24-27$ & 11 & 34.6 & 6.3 & \\
\hline \multirow[t]{4}{*}{$\mathrm{pH}$} & Calf & $\mathrm{I}$ & 11 & $7.41^{\mathrm{a}}$ & 0.07 & $7.36 \pm 0.0 \mathrm{I}^{14}$ \\
\hline & & 3 & 13 & 7.45 & 0.04 & $7.39 \pm 0.01^{14}$ \\
\hline & & 6 & 37 & $7.48^{\mathrm{b}}(P<0.00 \mathrm{I})$ & 0.06 & $7.41 \pm 0.03^{14}$ \\
\hline & Cow & $24-27$ & 11 & 7.47 & 0.13 & \\
\hline \multirow[t]{6}{*}{$\mathrm{P}_{\mathrm{a}} \mathrm{O}_{2}, \mathrm{mmHg}$} & Calf & 1 & 11 & 52.6 & 7.3 & $100 \pm 2.3^{23}$ \\
\hline & & & & & & $87.0 \pm 5.3^{14}$ \\
\hline & & & & & & $93.6 \pm 7.7^{15}$ \\
\hline & & 3 & 13 & 56.6 & 7.2 & $105.8 \pm 5.3^{14}$ \\
\hline & & 6 & 37 & 53.9 & 10.9 & $103.5 \pm 2.3^{14}$ \\
\hline & Cow & $24-27$ & 11 & 59.4 & 9.0 & \\
\hline \multirow{8}{*}{$\begin{array}{l}\text { Alveolar-arterial } \mathrm{O}_{2} \\
\text { pressure gradient, } \\
\mathrm{mmHg}\end{array}$} & Calf & I & 11 & 8.5 & 5.6 & $15.8 \pm 5.3^{14}$ \\
\hline & & & & & & $17.3 \pm 1.5(17 \text { days old, sea level, } n=5)^{23}$ \\
\hline & & 3 & 13 & 11.7 & 5.4 & $1.5 \pm 3.0^{14}$ \\
\hline & & & & & & $1 \mathrm{I} .3 \pm 0.8(\mathrm{I} 35 \text { days, } \mathrm{n}=\mathrm{II})^{23}$ \\
\hline & & 6 & 37 & 11.6 & 9.1 & $7.5 \pm 0.8(228 \text { days, } n=5)^{23}$ \\
\hline & & & & & & $0.8 \pm 0.8^{14}$ \\
\hline & Cow & $24-27$ & 11 & $6 . I^{*}(P=0.02)$ & 5.0 & $1.5 \pm 0.4(>1 \text { year old, } n=19)^{23}$ \\
\hline & & & & & & $18.0 \pm 3.8(\mathrm{HF} \text { cows, } \mathrm{n}=7)^{24}$ \\
\hline Oxyhemoglobin & Calf & 1 & 11 & $80.3^{\mathrm{a}}$ & 10.3 & $95.0 \pm 0.4^{14}$ \\
\hline \multirow[t]{3}{*}{ saturation, $\%$} & & 3 & 13 & $91.3^{\mathrm{b}}(P=0.005)$ & 3.2 & $96.9 \pm 0.4^{14}$ \\
\hline & & 6 & 37 & $89.2^{\mathrm{b}}(P=0.007)$ & 9.1 & $96.3 \pm 0.3^{14}$ \\
\hline & Cow & $24-27$ & 11 & 92.9 & 2.7 & \\
\hline L-lactate ${ }^{\dagger}$ & Calf & I & 12 & 3.2 & 2.8 & $<1.3(3-4 \text { days old, } n=16)^{34}$ \\
\hline \multirow[t]{7}{*}{$\mathrm{mmol} / \mathrm{L}$} & & & & Median $=1.9$ & & \\
\hline & & 3 & 5 & 2.7 & 2.5 & \\
\hline & & & & Median $=1.42$ & & \\
\hline & & 6 & 18 & 3.4 & 3.0 & \\
\hline & & & & Median $=3.0$ & & \\
\hline & Cow & $24-27$ & 9 & 6.5 & 6.3 & $0.54(n=34)^{35}$ \\
\hline & & & & Median $=3.42$ & & \\
\hline \multirow[t]{5}{*}{ Hematocrit, \% } & Calf & 1 & 0 & - & - & $34.8 \pm 7.3(\text { sea level, } n=20)^{15}$ \\
\hline & & 3 & 9 & 35.7 & 2.7 & \\
\hline & & 6 & 26 & 35.6 & 3.6 & $33 \pm 4.6(n=4 I)^{17}$ \\
\hline & Cow & $24-27$ & 5 & $31.4 *(P=0.05)$ & 3.4 & $38 \pm 4.1^{36}$ \\
\hline & & & & & & $38 \pm 5^{31}$ \\
\hline \multirow[t]{5}{*}{ Hemoglobin, g/L } & Calf & 1 & 0 & - & - & $110 \pm 22.1^{15}$ \\
\hline & & 3 & 9 & 121.2 & 8.7 & \\
\hline & & 6 & 25 & 121.1 & 11.5 & $113 \pm 14(n=41)^{17}$ \\
\hline & Cow & $24-27$ & 5 & $107.0 *(P=0.05)$ & 10.6 & $128.0 \pm 12.8(\text { elevation } 520 \mathrm{~m}, \mathrm{n}=59)^{36}$ \\
\hline & & & & & & $138.0 \pm 21.0^{31}$ \\
\hline
\end{tabular}

Notes: a,b Mean calf values that lack a common superscript (a or b) differ statistically $(P \leq 0.05)$. Mean calf values without a superscript do not differ statistically from mean values at any other age $(P>0.05)$; ${ }^{*}$ The mean value for 3 month old calves differs statistically from the mean value of their dams $(P \leq 0.05)$. ${ }^{\dagger}$ Median averages are provided for L-lactate due to the lack of a normal distribution.

Abbreviations: $n$, number of calves sampled; $S D$, standard deviation.

in the Rocky Mountains. Springtime calving is most common in Colorado, ${ }^{19}$ and takes place within close proximity of a stockman's house so that feed and assistance can be provided. Cows are grazed with calves on higher-altitude mountainous pastures during the summer months after the winter snow has melted. In the autumn, cows and newly weaned calves are brought down to the sheltered overwintering pastures located at lower altitudes.

Pulmonary arterial pressure was moderately autocorrelated: calves with the highest pulmonary arterial pressures at 
Table 4 Serum biochemical values for calves and cows

\begin{tabular}{|c|c|c|c|c|c|c|}
\hline Variable & Cow/calf & Age, months & $\mathbf{n}$ & Mean & SD & Reference \\
\hline \multirow[t]{10}{*}{ Total calcium, mmol/L } & Calf & 1 & 14 & $\begin{array}{l}2.76^{\mathrm{b}} \\
\left(P^{[\mathrm{b}=\mathrm{a}]}=0.04\right)\end{array}$ & 0.11 & $2.60 \pm 0.22(n=43)^{29}$ \\
\hline & & 3 & 17 & $2.68^{\mathrm{a}}$ & 0.08 & $2.62 \pm 0.21(n=53)^{29}$ \\
\hline & & & & & & $2.27(n=20)^{30}$ \\
\hline & & & & & & $2.8 \pm 0.3(n=46)^{31}$ \\
\hline & & 6 & 44 & $2.76^{\mathrm{b}}$ & 0.07 & $2.66 \pm 0.18(n=39)^{29}$ \\
\hline & & & & $\left(P^{[\mathrm{b}=\mathrm{a}]}=0.007\right)$ & & $2.54 \pm 0.10(n=42)^{17}$ \\
\hline & & & & & & $2.5 \pm 0.2(n=46)^{31}$ \\
\hline & Cow & $24-27$ & 25 & $2.53 *(P<0.00 \mathrm{I})$ & 0.1 & $2.0 \pm 0.2^{36}$ \\
\hline & & & & & & $2.3 \pm 0.2^{31}$ \\
\hline & & & & & & $2.3 \pm 0.1^{37}$ \\
\hline \multirow[t]{4}{*}{ lonized calcium, mmol/L } & Calf & 1 & - & - & - & $1.34 \pm 0.08(n=43)^{29}$ \\
\hline & & 3 & 10 & 1.34 & 0.03 & $1.33 \pm 0.08$ (elevation $\approx 120 \mathrm{~m}, \mathrm{n}=53)^{29}$ \\
\hline & & 6 & 25 & 1.33 & 0.1 & $1.27 \pm 0.05(n=39)^{29}$ \\
\hline & Cow & $24-27$ & 5 & $1.20 *(P<0.001)$ & 0.02 & $1.18 \pm 0.06(n=\mid 4 I)^{37}$ \\
\hline \multirow[t]{8}{*}{ Phosphorous, $\mathrm{mmol} / \mathrm{L}$} & Calf & I & 14 & $2.86^{\mathrm{a}}$ & 0.26 & \\
\hline & & 3 & 17 & $3.16^{\mathrm{b}}$ & 0.21 & $2.13(n=20)^{30}$ \\
\hline & & & & $\left(P^{[\mathrm{b}=\mathrm{a}]}=0.006\right)$ & & $3.0 \pm 0.4(n=46)^{31}$ \\
\hline & & 6 & 44 & $2.23^{c}$ & 0.33 & $2.61 \pm 0.32(n=42)^{17}$ \\
\hline & & & & $\left(P^{[\mathrm{c}=\mathrm{a}]}<0.00 \mathrm{I}\right)$ & & $2.6 \pm 0.2(n=46)^{31}$ \\
\hline & & & & $\left(P^{[c=b]}<0.001\right)$ & & \\
\hline & Cow & $24-27$ & 25 & $2.40 *(P<0.00 I)$ & 0.45 & $\mathrm{I} .4 \pm 0.4^{36}$ \\
\hline & & & & & & $1.6 \pm 0.3^{31}$ \\
\hline \multirow[t]{8}{*}{ Creatinine, $\mu \mathrm{mol} / \mathrm{L}$} & Calf & 1 & 13 & $110.2^{\mathrm{a}}$ & 18.7 & \\
\hline & & 3 & 17 & $93.1^{\mathrm{b}}$ & 14.8 & $81(n=20)^{30}$ \\
\hline & & & & $\left(P^{[\mathrm{b}=\mathrm{a}]}=0.02\right)$ & & $97.2 \pm 12.3(n=46)^{31}$ \\
\hline & & 6 & 44 & $137.6^{c}$ & 21.9 & $7 I \pm 9(n=4 I)^{17}$ \\
\hline & & & & $\left(P^{[\mathrm{c}=\mathrm{a}]}<0.00 \mathrm{I}\right)$ & & $92.3 \pm 9.4(n=46)^{31}$ \\
\hline & & & & $\left(P^{[c=b]}<0.00 I\right)$ & & \\
\hline & Cow & $24-27$ & 25 & 94.8 & 36.5 & $120 \pm 27.7^{36}$ \\
\hline & & & & & & $103.2 \pm 17.9^{31}$ \\
\hline \multirow[t]{7}{*}{ Sodium, mmol/L } & Calf & 1 & 18 & $138.1^{a}$ & 2.1 & \\
\hline & & 3 & 20 & $143.6^{\mathrm{b}}$ & 2.2 & $142(n=20)^{30}$ \\
\hline & & & & $\left(P^{[\mathrm{b}=\mathrm{a}]}<0.00 \mathrm{I}\right)$ & & \\
\hline & & 6 & 47 & $140.0^{c}$ & 2.1 & $|4| \pm 2.3(n=42)^{17}$ \\
\hline & & & & $\left(P^{[\mathrm{c}=\mathrm{a}]}<0.00 \mathrm{I}\right)$ & & \\
\hline & & & & $\left(P^{[c=b]}<0.00 I\right)$ & & \\
\hline & Cow & $24-27$ & 25 & $141.3 *(P=0.00 \mathrm{I})$ & 2.0 & $144 \pm 17.1^{36}$ \\
\hline \multirow[t]{5}{*}{ Potassium, mmol/L } & Calf & I & 18 & $5.1^{\mathrm{a}}$ & 0.3 & \\
\hline & & 3 & 20 & $5.0^{\mathrm{a}}$ & 0.4 & \\
\hline & & 6 & 47 & $4.4^{\mathrm{b}}$ & 0.5 & $4.2 \pm 0.4(n=42)^{17}$ \\
\hline & & & & $\left(P^{[\mathrm{b}=\mathrm{a}]}<0.00 \mathrm{I}\right)$ & & \\
\hline & Cow & $24-27$ & 25 & 4.8 & 0.4 & $5.1 \pm 0.8^{36}$ \\
\hline \multirow[t]{6}{*}{ Chloride, mmol/L } & Calf & I & 18 & $101.2^{\mathrm{a}}$ & 2.5 & \\
\hline & & 3 & 20 & $101.2^{\mathrm{b}}$ & 3.1 & $103.6(n=20)^{30}$ \\
\hline & & 6 & 47 & $99.5^{c}$ & 2.1 & $99 \pm 2.6(n=42)^{17}$ \\
\hline & & & & $\left(P^{[\mathrm{c}=\mathrm{a}]}=0.004\right)$ & & \\
\hline & & & & $\left(p^{[c=b]}=0.005\right)$ & & \\
\hline & Cow & $24-27$ & 25 & $98.6 *(P=0.004)$ & 2.0 & $105 \pm 13.9^{36}$ \\
\hline \multirow[t]{7}{*}{ Magnesium, mmol/L } & Calf & I & 18 & $0.78^{\mathrm{a}}$ & 0.08 & \\
\hline & & 3 & 20 & $0.89^{b}$ & 0.09 & \\
\hline & & & & $\left(P^{[\mathrm{b}=\mathrm{a}]}<0.00 \mathrm{I}\right)$ & & \\
\hline & & 6 & 47 & $0.97^{c}$ & 0.07 & $0.90 \pm 0.08(n=42)^{17}$ \\
\hline & & & & $\left(P^{[\mathrm{c}=\mathrm{a}]}<0.00 \mathrm{I}\right)$ & & \\
\hline & & & & $\left(P^{[c=b]}<0.001\right)$ & & \\
\hline & Cow & $24-27$ & 25 & $1.15^{*}(P<0.001)$ & 0.1 & $1.2 \pm 0.3^{36}$ \\
\hline
\end{tabular}

Notes: ${ }^{a-c}$ Mean calf values that lack a common superscript (a, b, or c) differ statistically $(P \leq 0.05)$. Mean calf values without a superscript do not differ statistically from mean values at any other age $(P>0.05)$; *The mean value for 3 -month-old calves differs statistically from the mean value of their dams $(P \leq 0.05)$.

Abbreviations: $n$, number of calves sampled; SD, standard deviation. 
1 month of age tended to have the highest pulmonary arterial pressures at 6 months of age. This may be because the effects of lung pathology on pulmonary arterial pressure in early life persist, or a genetic susceptibility to higher pulmonary arterial pressure exists from birth. Pulmonary arterial pressure is moderately heritable $(0.34 \pm 0.05),{ }^{20}$ but maternal pulmonary arterial pressure was not predictive of a calf's pulmonary arterial pressure at 3 months old. However, the phenotypic expression of pulmonary arterial pressure heritability increases from birth to weaning. ${ }^{21}$ Steers tended to have higher pulmonary arterial pressures than heifers at all ages. The difference became more pronounced with increasing age. A phenomenon known as "fat steer disease" has been reported in feedlot steers with similar manifestations to highaltitude disease, and this may reflect the greater tendency of steers to show elevated pulmonary arterial pressure relative to heifers found in this study.

Both calves and cows exhibited respiratory alkalosis due to hyperventilation, a classic response of lowland natives to high altitude. ${ }^{22}$ Alveolar-arterial oxygen pressure gradients $>10 \mathrm{mmHg}$ indicate that transfer of alveolar oxygen into the blood is impaired. A high alveolar-arterial oxygen pressure gradient is expected in young calves, but this should fall with increasing age as the efficacy of gas exchange improves concurrently with functional maturation of the lung. ${ }^{14,23}$ However, this was not the case. High mean alveolar-arterial oxygen pressure gradients were found in clinically healthy calves (8.5-11.7 $\mathrm{mmHg}$ ), indicating poor transfer of oxygen from the alveoli into the pulmonary blood. Previous estimates of alveolar-arterial oxygen pressure gradients vary greatly, ${ }^{14,23,24}$ but generally agree that alveolar-arterial oxygen pressure is above what should be expected $(<10 \mathrm{mmHg}$ ), even in healthy calves at sea level. The underlying physiological reason for this is not clear. Remarkably, hematocrit and hemoglobin concentrations were no more than $5 \%$ and $10 \mathrm{~g} / \mathrm{L}$ higher than age-matched calves at sea level, respectively. ${ }^{16,17,25}$ This is not sufficient to counter the reduction in atmospheric oxygen tension associated with high altitude and the poor transfer of oxygen from the alveoli into the pulmonary blood. High lactate levels due to substantial anaerobic respiration were found despite the low-stress handling of calves throughout the sampling process.

Cows had higher oxyhemoglobin saturation but a lower hematocrit than calves. This is important because low oxyhemoglobin saturation is predictive of pulmonary hypertension in both cattle ${ }^{26}$ and broiler chickens. ${ }^{27}$ One might anticipate calves to have higher oxyhemoglobin saturation than cows, since fetal hemoglobin, which has high affinity for oxygen, is detectable in calf blood until 6-7 months after birth. ${ }^{28}$ However, the oxyhemoglobin dissociation curve is sigmoidal. Oxyhemoglobin saturation drops precipitously below an oxygen tension of $60 \mathrm{mmHg}$. Mean calf $\mathrm{p}_{\mathrm{a}} \mathrm{O}_{2}$ tensions were as low as $52.6 \pm 7.3 \mathrm{mmHg}$ (1 month) and consistently lower than $59.4 \mathrm{mmHg}$, the mean value for cows.

The concentrations of serum calcium and phosphorous in calves were higher than in cows, reflecting increased turnover of skeletal mineral during growth. The concentrations of calcium and phosphorous in calves reported here are typically higher than in most prior studies. ${ }^{16,17,29-31}$ This may be related to rate of growth. High calcium and phosphorous concentrations may predispose calves to develop soft-tissue mineralization under certain pathologic states, such as pulmonary hypertension. ${ }^{5,32}$ Alkaline blood conditions, tissue injury, and hypoxia are all predisposing factors for mineralization of tissues. ${ }^{33}$

\section{Conclusion}

Beef calves 1, 3, and 6 months old at altitudes over $2410 \mathrm{~m}$ showed respiratory alkalosis and poor transfer of oxygen from the alveoli to the pulmonary blood. Anaerobic respiration in calves at rest suggests that the provision of oxygen to peripheral tissues may be compromised at altitudes over $2410 \mathrm{~m}$. Adequacy of oxygen delivery should be evaluated in future studies by estimating oxygen extraction ratio. High oxygen demand relative to supply may have implications for cardiopulmonary disease susceptibility. Further studies are needed to determine whether these findings are unique to the high-altitude environment or are shared by calves at more moderate altitudes.

\section{Acknowledgments}

The authors would like to thank: Barbara East and Bryan Neves for greatly assisting the collection of field samples; Bill Trampe for use of facilities and access to study calves; and Dr Elizabeth Frazer for initiating the study and continued support. Funding for this research came from CSU College of Veterinary Medicine and Biomedical Sciences College Research Council and Integrated Livestock Management producer donations. Publication funding was generously provided by the Colorado State University Libraries Open Access Research and Scholarship Fund.

\section{Disclosure}

The authors report no conflicts of interest in this work. 


\section{References}

1. Durmowicz AG, Hofmeister S, Kadyraliev TK, Aldashev AA, Stenmark KR. Functional and structural adaptation of the yak pulmonary circulation to residence at high altitude. J Appl Physiol. 1993; 74(5):2276-2285.

2. National Agricultural Statistics Service (NASS). Statistics of Cattle, Hogs, and Sheep. NASS; 2010. Available from: http://www.nass. usda.gov/Publications/Ag_Statistics/2010/Chapter07.pdf. Accessed February 8, 2011.

3. Glover GH, Newsom IE. Brisket Disease (Dropsy of High Altitude). Volume 204 of Colorado Agri. Exp. Station Bulletin. Colorado Agricultural Experiment Station; Fort Collins, CO; 1915.

4. Hecht HH, Kuida H, Lange RL, Horne JL, Brown AM. Brisket disease. II. Clinical features and hemodynamic observations in altitudedependent right heart failure of cattle. Am J Med. 1962;32:171-183.

5. Neary JM, Gould DH, Garry FB, Knight AP, Dargatz DA, Holt TN. An investigation into beef calf mortality on 5 high-altitude ranches that selected sires with low pulmonary arterial pressures for over 20 years. J Vet Diagn Invest. 2013;25(2):210-218.

6. Holt T, Callan R. Pulmonary arterial pressure testing for high mountain disease in cattle. Vet Clin North Am Food Anim Pract. 2007;23(3): 575-596.

7. Nagy O, Kovac G, Seidel H, Paulikova I. Selection of arteries for blood sampling and evaluation of blood gases and acid-base balance in cattle. Acta Veterinaria Brno. 2002;71(3):289-296.

8. Collie DD. Blood gas and acid-base values in calves, sampled from the brachial and coccygeal arteries. Br Vet J. 1991;147(3):232-237.

9. Hopper K, Rezende ML, Haskins SC. Assessment of the effect of dilution of blood samples with sodium heparin on blood gas, electrolyte, and lactate measurements in dogs. Am J Vet Res. 2005;66(4):656-660.

10. Hutchison AS, Ralston SH, Dryburgh FJ, Small M, Fogelman I. Too much heparin: possible source of error in blood-gas analysis. $\mathrm{Br} \mathrm{Med}$ $J$ (Clin Res Ed). 1983;287(6399):1131-1132.

11. CLSI Document C46-A. Blood Gas and pH Analysis and Related Measurements; Approved Guideline. Wayne, PA: CLSI; 2001.

12. Lekeux P. Pulmonary Function in Healthy, Exercising and Diseased Animals. Ghent: University of Ghent; 1993.

13. Gallivan GJ, McDonell WN, Forrest JB. Comparative ventilation and gas exchange in the horse and the cow. Res Vet Sci. 1989;46(3):331-336.

14. Nagy O, Seidel H, Kovac G, Paulikova I. Acid-base balance and blood gases in calves in relation to age and nutrition. Czech J Anim Sci. 2003; 48(2):61-68.

15. Donawick WJ, Baue AE. Blood gases, acid-base balance and alveolar-arterial oxygen gradient in calves. Am J Vet Res. 1968;29(3): 561-567.

16. Mohri M, Sharifi K, Eidi S. Hematology and serum biochemistry of Holstein dairy calves: Age related changes and comparison with blood composition in adults. Res Vet Sci. 2007;83(1):30-39.

17. Lumsden JH, Mullen K, Rowe R. Hematology and biochemistry reference values for female Holstein cattle. Can J Comp Med. 1980; 44(1):24-31.

18. Jensen R, Pierson RE, Braddy PM, et al. Brisket disease in yearling feedlot cattle. J Am Vet Med Assoc. 1976;169(5):515-517.

19. Neary JM. Pre-Weaned Beef Calf Mortality on High Altitude Ranches in Colorado [master's thesis]. Fort Collins, CO, Colorado State University; 2013.

Open Access Animal Physiology

\section{Publish your work in this journal}

Open Access Animal Physiology is an international, peer-reviewed, open access journal publishing original research, reports, reviews and commentaries on all areas of animal physiology. The manuscript management system is completely online and includes a very
20. Shirley KL, Beckman DW, Garrick DJ. Inheritance of pulmonary arterial pressure in Angus cattle and its correlation with growth. J Anim Sci. 2008;86(4):815-819.

21. Levalley SB. Pulmonary Hypertension in Beef Cattle [master's thesis]. Fort Collins, CO, Colorado State University; 1978.

22. Monge $\mathrm{C}$, Leonvelarde F. Physiological adaptation to high-altitude: oxygen transport in mammals and birds. Physiol Rev. 1991;71(4): 1135-1172.

23. Lekeux P, Hajer R, Breukink HJ. Effect of somatic growth on pulmonary function values in health Freisian cattle. Am JVet Res. 1984; 45(10):2003-2007.

24. Gallivan GJ, Viel L, Baird JD, McDonell WN. Pulmonary structure and function in adult dairy cows with an expanded lung field. Can J Vet Res. 1991;55(1):15-20.

25. Brun-Hansen HC, Kampen AH, Lund A. Hematologic values in calves during the first 6 months of life. Vet Clin Pathol. 2006;35(2): $182-187$.

26. Will DH, Reeves JT, Alexander AF, Grover RF. High altitude induced pulmonary hypertension in normal cattle. Circ Res. 1962;10(2): $172-177$.

27. Wideman RF Jr, Wing T, Kirby YK, et al. Evaluation of minimally invasive indices for predicting ascites susceptibility in three successive hatches of broilers exposed to cool temperatures. Poult Sci. 1998; 77(10):1565-1573.

28. Lee CK, Odell GV, Eliot FP, Anderson IL, Jones EW. Postnatal loss of bovine fetal hemoglobin. Am J Vet Res. 1971;32(7):1039-1044.

29. Agnes F, Sartorelli P, Bisso MC, Dominoni S. Ionized calcium in calf serum: relation to total serum calcium, albumin, total protein and $\mathrm{pH}$. Zentralbl Veterinarmed A. 1993;40(8):605-608.

30. Dubreuil P, Lapierre H. Biochemistry reference values for Quebec lactating dairy cows: Nursing sows, growing pigs and calves. Can J Vet Res. 1997;61(3):235-239.

31. Doornenbal H, Tong AKW, Murray NL. Reference values of blood parameters in beef cattle of different ages and stages of lactation. Can J Vet Res. 1988;52(1):99-105.

32. Alexander AF, Jensen R. Pulmonary vascular pathology of bovine high mountain disease. Am J Vet Res. 1963;24:1098-1111.

33. Abedin M, Tintut Y, Demer LL. Vascular calcification: mechanisms and clinical ramifications. Arterioscler Thromb Vasc Biol. 2004;24(7): 1161-1170.

34. Constable PD, Streeter RN, Koenig GJ, et al. Determinants and utility of the anion gap in predicting hyperlactatemia in cattle. $J$ Vet Intern Med. 1997;11(2):71-79.

35. Figueiredo MD, Nydam DV, Perkins GA, et al. Prognostic value of plasma L-lactate concentration measured cow-side with a portable clinical analyzer in Holstein dairy cattle with abomasal disorders. J Vet Intern Med. 2006;20(6):1463-1470.

36. Grünwaldt EG, Guevara JC, Estévez OR, et al. Biochemical and haematological measurements in beef cattle in Mendoza plain rangelands (Argentina). Trop Anim Health Prod. 2005;37(6):527-540.

37. Lincoln SD, Lane VM. Serum ionized calcium concentration in clinically normal dairy cattle and changes associated with calcium abnormalities. J Am Vet Med Assoc. 1990;197(11):1471-1474.

\section{Dovepress}

quick and fair peer-review system. Visit http://www.dovepress.com/ testimonials.php to read real quotes from published authors. 